Nowoczesne Systemy Zarządzania

Zeszyt 12 (2017), nr 3 (lipiec-wrzesień)

ISSN 1896-9380, s. 59-80

Modern Management Systems

Volume 12 (2017), No. 3 (July-September)

ISSN 1896-9380, pp. 59-80
Instytut Organizacji i Zarządzania

Wydział Cybernetyki

Wojskowa Akademia Techniczna

w Warszawie

Institute of Organization and Management

Faculty of Cybernetics

Military University of Technology

\title{
Procesy planowania w przedsiębiorstwach na rynku NewConnect ${ }^{1}$
}

\section{Planning processes in enterprises on NewConnect market}

\author{
Jacek Woźniak \\ Wojskowa Akademia Techniczna \\ Wydział Cybernetyki
}

\begin{abstract}
Abstrakt. Zasadniczym celem artykułu jest wskazanie, w jakim zakresie i w jakiej skali stosowane są technologie teleinformatyczne $w$ realizacji procesów planowania w przedsiębiorstwach notowanych na rynku NewConnect w Polsce. W artykule przedstawione zostały wyniki badania empirycznego. Zastosowana metoda badawcza to Computer Assisted Self-Interviewing (CASI). Z przeprowadzonego badania wynika, że technologie teleinformatyczne są dostrzegane przez przedsiębiorstwa notowane na rynku NewConnect i powszechnie wdrażane w kluczowych aspektach procesów planowania lub zarządzania zasobami informacyjnymi (realizowanego na potrzeby planowania). Jednakże nie zawsze doceniany jest ich dodatni wpływ na tego typu procesy, zwłaszcza w zakresie wsparcia działań analitycznych.
\end{abstract}

Słowa kluczowe: procesy planowania, rynek NewConnect, technologie teleinformatyczne (ICT), przedsiębiorstwo, zarządzanie zasobami informacyjnymi

Abstract: The principal purpose of the article is to indicate to what extent and in what scale ICTs are used in the implementation of planning processes in companies listed on the NewConnect market in Poland. Empirical research results are presented in the paper. The applied research method is Computer Assisted Self-Interviewing (CASI). The study shows that ICTs are perceived by companies listed on the NewConnect market and widely deployed in key aspects of planning processes or information resources management processes (carried out for planning function). However, it is not always appreciated their (ICTs') positive impact on this type of processes, especially in terms of supporting analytical functions.

Keywords: planning processes, NewConnect market, Information and Communication Technologies (ICTs), enterprise, information resources management

1 Artykuł został sfinansowany ze środków publicznych i napisany w ramach pracy badawczej nr RMN 812/2016 (Wydział Cybernetyki, Wojskowa Akademia Techniczna w Warszawie). Badanie empiryczne zostało wykonane przez firmę Centrum Badań Marketingowych INDICATOR Sp. z o.o. z siedzibą w Warszawie (ul. Świętojerska 5/7, 00-236 Warszawa). 


\section{Wstęp}

Współcześnie przedsiębiorstwa w wielu gospodarkach krajowych - również w Polsce - klasyfikowane są z wykorzystaniem różnych kryteriów. Takie działania mają na celu nie tylko zwiększenie przejrzystości struktury przedmiotowej przedsiębiorstw i ułatwienie ich ewidencji, ale również (jeśli nie przede wszystkim) usprawnienie systemu wsparcia tych przedsiębiorstw (np. w zakresie regulacji, a także finansowania ich działalności). Do podstawowych kryteriów klasyfikacji przedsiębiorstw zalicza się m.in.: wielkość i wiek przedsiębiorstwa, branżę i sektor w jakim działa, jak również skalę prowadzonej działalności, poziom innowacyjności, skłonność do ryzyka, elastyczność w działaniu operacyjnym itd. Niektóre ze wskazanych przykładowych kryteriów są charakterystyczne dla określonych branż i rynków, np. skłonność do ryzyka i poziom innowacyjności. Warto też podkreślić, że kryteria te warunkują m.in. sprawność i skuteczność realizacji funkcji zarządzania - w tym planowania.

Powyższa sytuacja występuje w przypadku przedsiębiorstw notowanych na rynku NewConnect (NC) - jest to specyficzny zbiór podmiotów gospodarczych, ukierunkowanych głównie za zewnętrzne finansowanie działalności innowacyjnej, obarczonej względnie wysokim poziomem ryzyka (NewConnect, 2017). W przedsiębiorstwach tego typu szczególnie duże znaczenie mają procesy planowania, które określają m.in.: kierunek rozwoju w obszarze działalności innowacyjnej i projektowej, strategię rozwoju (np. w niszach rynkowych), system zarządzania ryzykiem rynkowym, czy też dywersyfikację źródeł finansowania inwestycji - a więc warunkują (zazwyczaj pośrednio) potencjał tych przedsiębiorstw do rozwoju i wartość dla interesariuszy zewnętrznych, tj. podmiotów finansujących te przedsiębiorstwa. Szczególnie ważne jest to, aby procesy planowania w przedsiębiorstwach, które z założenia są innowacyjne, elastyczne i działają w warunkach podwyższonego ryzyka rynkowego, wykorzystywały określone technologie teleinformatyczne (ICT) ${ }^{2}$.

Zasadniczym celem artykułu jest wskazanie, w jakim zakresie i w jakiej skali stosowane są technologie teleinformatyczne $\mathrm{w}$ realizacji procesów planowania w przedsiębiorstwach notowanych na rynku NewConnect w Polsce. W artykule następuje wstępna identyfikacja specyfiki podejścia przedsiębiorstw w obszarze realizacji różnych aspektów funkcji planowania wspomaganej technologiami teleinformatycznymi. Jest to swoiste wsparcie merytoryczne dla dalszych, pogłębionych badań empirycznych. Podstawową metodą badawczą jest wywiad przeprowadzony

2 Główny Urząd Statystyczny definiuje ICT następująco: „rodzina technologii przetwarzających, gromadzacych i przesyłających informacje w formie elektronicznej" (Istshare.eu, 2017). Technologie teleinformatyczne obejmują: sprzęt komputerowy (komputery wraz z oprogramowaniem) i sieci komputerowe (systemy komunikacyjne wykorzystujące m.in. technologie internetowe) (Wrycza, 2010, s. 21). 
$\mathrm{w}$ formie ankiety wypełnianej samodzielnie przez respondenta $\mathrm{z}$ wykorzystaniem komputera i przy bezpośrednim wsparciu ankietera (CASI - ang. Computer Assisted Self-Interviewing). W badaniu stosowane są również metody analizy, syntezy i dedukcji.

\section{Specyfika rynku NewConnect}

Rynek NewConnect jest rynkiem alternatywnym organizowanym przez Giełdę Papierów Wartościowych (GPW) w Warszawie. Ogólnie przyjmuje się, że alternatywny system obrotu to rynek pozagiełdowy, który jest organizowany przez firmę inwestycyjną lub spółkę prowadzącą rynek regulowany. Przedmiotem obrotu na rynkach alternatywnych są papiery wartościowe oraz instrumenty rynku pieniężnego. Rynki alternatywne oferują inwestorom atrakcyjne możliwości alokacji kapitału w różnych innowacyjnych branżach. Przedsiębiorstwa notowane na takich rynkach oferują inwestorom potencjalnie wysoki zwrot $z$ inwestycji przy jednocześnie podwyższonym ryzyku. Inwestorzy nie są pewni, w jaki sposób będzie zmieniał się rynek, na którym działają przedsiębiorstwa, a także czy efektywność zewnętrzna działalności przedsiębiorstwa będzie na oczekiwanym poziomie (Woźniak, Wereda, 2018).

Rynek NewConnect powstał 30 sierpnia 2007 roku. Utworzono go z myślą o małych i średnich przedsiębiorstwach o wysokim potencjale wzrostu, które chcą pozyskać kapitał na rozwój. Głównym celem uruchomienia rynku alternatywnego przez Giełdę Papierów Wartościowych w Warszawie było umożliwienie rozwoju małym i średnim spółkom, które napotykały trudności w pozyskiwaniu finansowania na rozwój. NewConnect oferuje bardziej liberalne wymogi formalne i obowiązki informacyjne niż Główny Rynek GPW, a co za tym idzie tańsze pozyskanie kapitału, który spółki wykorzystują w celu realizacji założonej strategii rozwoju na rynku. Dla coraz większej liczby emitentów rynek NewConnect jest początkiem drogi na Główny Rynek GPW w Warszawie (NewConnect, 2015, s. 15).

\section{Atrybuty przedsiębiorstw notowanych na rynku NewConnect}

Przedsiębiorstwa notowane na rynkach alternatywnych, w tym także na rynku NewConnect, odznaczają się przede wszystkim (rys. 1):

- wysokim potencjałem wzrostu oraz elastycznością i zwinnością - związane jest to $\mathrm{z}$ tym, że funkcjonują w branżach i sektorach innowacyjnych, będących odzwierciedleniem nisz rynkowych, np. w obszarze zaawansowanych technologii, ekologii, usług specjalistycznych lub też działalności finansowej; 
- małą lub średnią wielkością - są to głównie nowo powstałe podmioty gospodarcze (np. start-upy) lub przedsiębiorstwa we wczesnych fazach rozwoju ${ }^{3}$;

- chęcią względnie szybkiego pozyskania kapitału na rozwój, która wynika m.in. z wysokiego wskaźnika kapitałochłonności realizowanych procesów, nieprzewidywalności rynku (działania konkurentów oraz zachowania nabywcze klientów), a także długiego okresu opracowywania, wdrażania i komercjalizacji innowacji;

- trudnościami w pozyskiwaniu finansowania na rozwój - głównie dlatego, że rynki są słabo rozwinięte oraz popyt na wyroby i usługi może nie być na dostatecznie wysokim poziomie, a także może występować względnie niski poziom zaufania społecznego dla działalności tych przedsiębiorstw (utrudnione jest zatem finansowanie w formie pożyczek i kredytów oferowanych przez banki albo też koszt kapitału oferowanego przez banki jest zbyt wysoki).

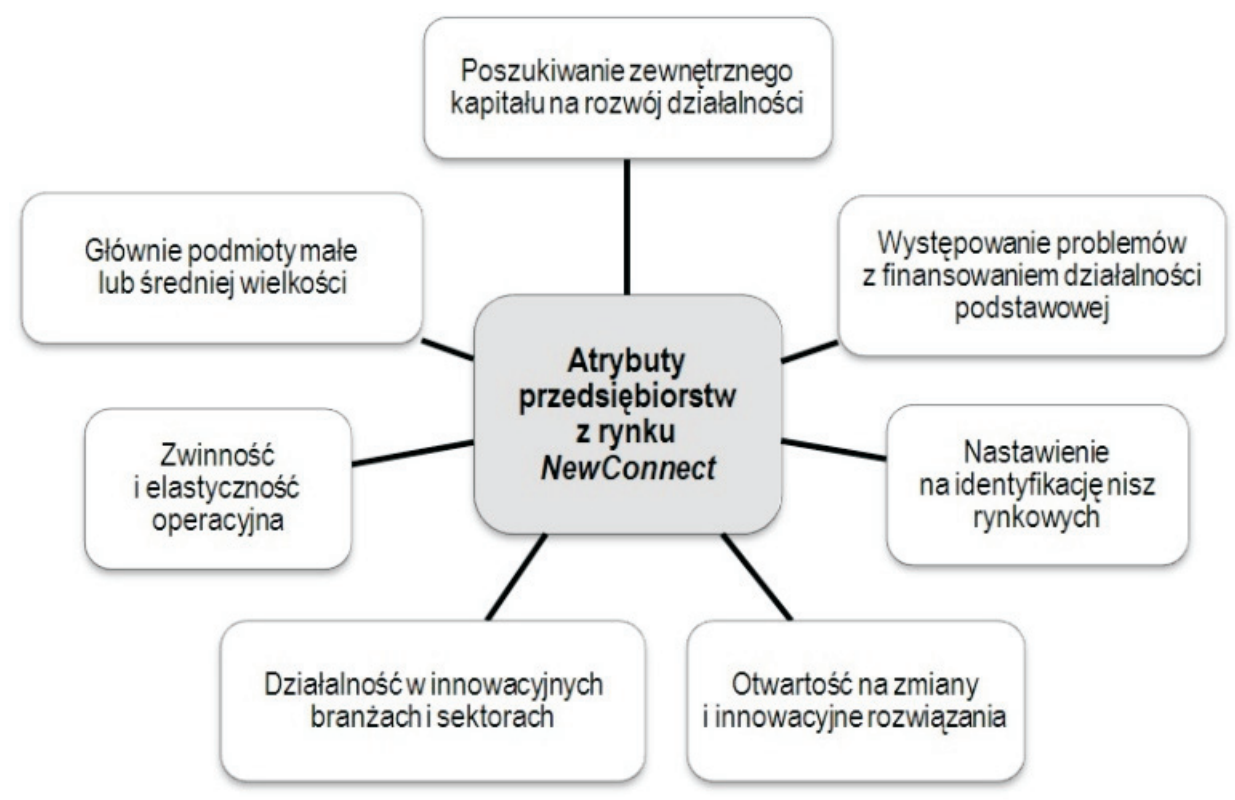

Rys. 1. Podstawowe atrybuty przedsiębiorstw notowanych na rynku NewConnect Źródło: opracowanie własne na podstawie: NewConnect, 2017

3 Na rynku NewConnect są również notowane przedsiębiorstwa z ugruntowaną pozycją na rynku i długą historią działalności, które jednak z różnych względów nie chcą lub nie mogą wejść na Główny Rynek GPW w Warszawie. 
Atrybuty przedsiębiorstw notowanych na rynku NewConnect mogą sugerować względnie wysoki poziom ryzyka podejmowanej działalności. Jednym z podstawowych działań w zakresie sterowania ryzykiem w przedsiębiorstwach jest redukowanie ujemnego wpływu zagrożeń, a także unikanie zagrożeń (ISO, 2009). Jest to jednak podejście „tradycyjne”. W myśl nowoczesnego podejścia do zarządzania ryzykiem (Kasiewicz, Rogowski, 2006, s. 34; Krysiak, 2011; Turek, 2012, s. 44-57; Bombiak, 2017, s. 122-123), ryzykiem steruje się w celu kreowania tzw. czynników szans. Specyfika działalności przedsiębiorstw na rynku NewConnect wymaga wchodzenia $\mathrm{w}$ interakcje $\mathrm{z}$ interesariuszami zewnętrznymi, np. w zakresie pozyskiwania zasobów, usprawniania przepływu informacji oraz nawiązywania nowych i trwałych relacji aby ograniczać poziom niepewności i ryzyka oraz wykorzystywać potencjał szans (Sosiński, 2011, s. 133 i nast.; Wojtysiak-Kotlarski, 2011, s. 246-247; Cielemęcki, Bombiak, 2016, s. 135-142).

\section{Procesy planowania w przedsiębiorstwach na rynku NewConnect - perspektywa zastosowania technologii teleinformatycznych}

Jednym $\mathrm{z}$ rozwiązań mających na celu kreowanie wspomnianych powyżej szans jest wdrażanie technologii teleinformatycznych. Warto jednak pamiętać, że technologie te są zarówno nośnikiem zagrożeń, jak i czynnikiem zwiększającym poziom bezpieczeństwa prowadzonej działalności gospodarczej. Do głównych kreowanych pośrednio - korzyści z wdrażania technologii teleinformatycznych w przedsiębiorstwach notowanych na rynku NewConnect można zaliczyć m.in. (Jurga, 2010, s. 49-53; Drab-Kurowska, 2011, s. 131-132; Woźniak, Wereda, 2018):

- usprawnianie procesów zarządzania finansami oraz podnoszenie efektywności alokacji pozyskiwanego kapitału;

- wspieranie i stymulowanie działalności innowacyjnej;

- umożliwienie wchodzenia przedsiębiorstw w struktury sieciowe (wirtualne), a także zwiększanie skali i zakresu działalności podstawowej (Wróbel, 2010, s. 86 i nast.);

- podnoszenie efektywności kanałów dystrybucji oraz promowania wyrobów i usług.

Warto jednak zaznaczyć, że wskazane powyżej korzyści są pochodną przede wszystkim wsparcia procesów zarządzania zasobami informacyjnymi, które można traktować jako podstawę funkcji planowania w przedsiębiorstwie. Szczególnie należy mieć tu na względzie realizację procesów związanych m.in. z: zasileniami informacyjnymi określonych komórek organizacyjnych i stanowisk, magazynowaniem, przetwarzaniem i analizowaniem danych oraz informacji, a także kreowaniem i udostępnianiem wiedzy (Larose, 2006, s. 3 i nast.; Orzechowski, 2008, 
s. 17 i nast.; Surma, 2009, s. 14 i nast.; Zaskórski, 2012, s. 209 i nast.). Technologie teleinformatyczne mają również znaczenie $\mathrm{w}$ realizacji procesów komunikowania się poszczególnych pracowników w strukturze organizacyjnej - zarówno w układzie wertykalnym, jak i horyzontalnym (Drab-Kurowska, 2011, s. 141-147). Dzięki ICT możliwe jest zatem zaistnienie silnego i dodatniego efektu synergii w procesach wymiany zasobów informacyjnych i kreowania wiedzy (np. w zespołach wirtualnych), która w dalszej kolejności może być stosowana w procesach planowania. Nie bez znaczenia dla wsparcia procesów planowania jest również umożliwienie tworzenia repozytorium zasobów informacyjnych w organizacji, dzięki czemu w przedsiębiorstwie mogą być realizowane funkcje analityczno-raportujące oraz ewidencyjne. ICT stanowią także swoistą platformę tworzenia i obiegu dokumentacji zarówno wewnątrz przedsiębiorstwa, jak i w relacjach z podmiotami zewnętrznymi (Zaskórski, 2012, s. 202 i nast.).

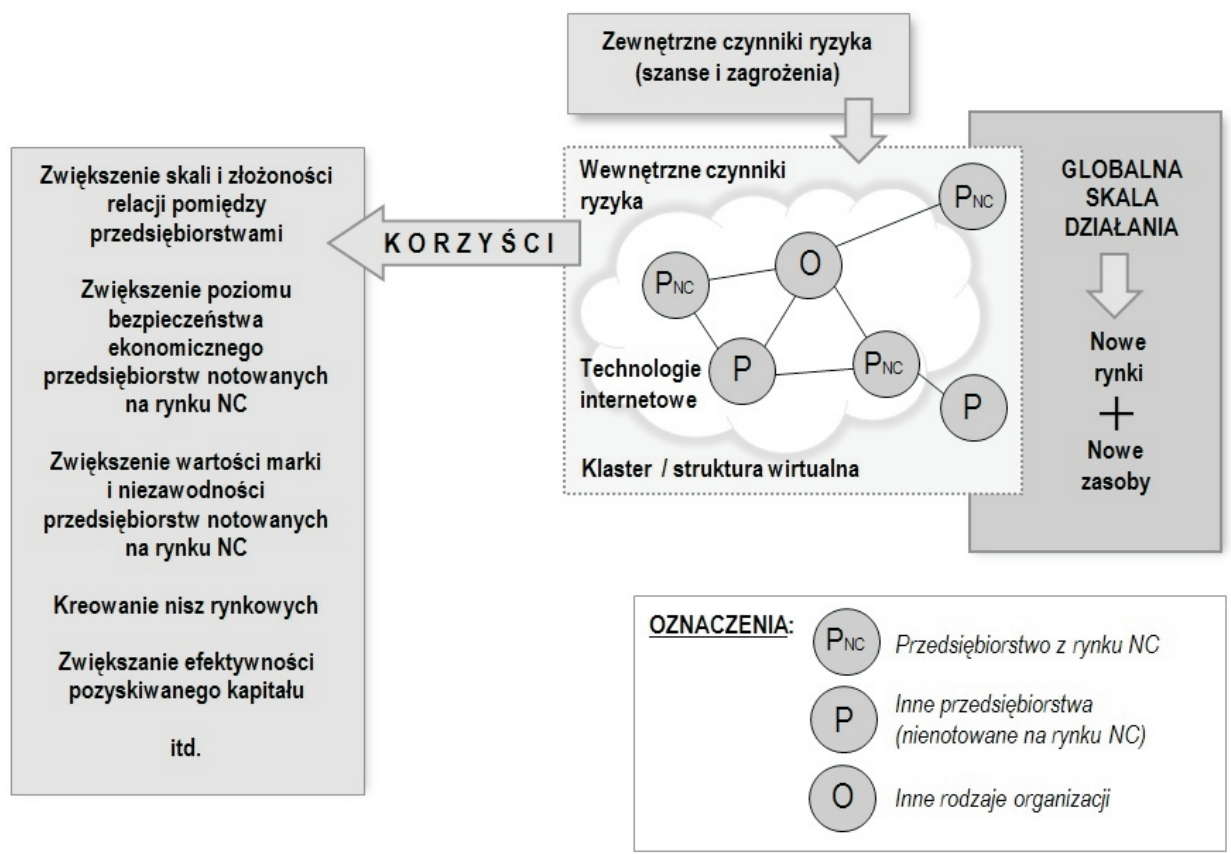

Rys. 2. Podstawowe korzyści z zastosowania technologii teleinformatycznych $\mathrm{w}$ procesach planowania w przedsiębiorstwach notowanych na rynku NewConnect

Źródło: opracowanie własne

Biorąc pod uwagę wsparcie procesów planowania przez wdrażanie ICT, warto odnieść się do holistycznego postrzegania działalności współczesnych przedsiębiorstw, ujmującego przedsiębiorstwa jako systemy działania złożone z podsystemów i jednocześnie będące podsystemami określonych nadsystemów (Koźmiński, 
Latusek-Jurczak, 2011, s. 42 i nast.; Zaskórski, 2014, s. 9-13). Planowanie, sprowadzające się w głównej mierze do ustalania celów, zarówno w długim, jak i krótkim okresie (Griffin, 2006, s. 9, 211 i nast.; Skrzypek, Hofman, 2010, s. 38 i nast.; Niemczyk, 2013, s. 82 i nast.) związane jest z koniecznością podejmowania decyzji, nierzadko wymagających integracji różnych - nawet sprzecznych - dążeń określonych grup interesariuszy przedsiębiorstwa (Mintzberg, 2013, s. 191-193), jak i odznaczających się dużą złożonością (Goodwin, Wright, 2011, s. 19 i nast.). Planowanie wpływa na strukturę zarówno zasileń przedsiębiorstw - $\mathrm{w}$ formie rożnych klas zasobów - jak i rezultatów działalności tych przedsiębiorstw - pod postacią wyrobów, usług lub projektów, a także braków, błędów, usterek oraz zasobów danych, informacji i wiedzy (Koźmiński, Latusek-Jurczak, 2011, s. 43-44; Woźniak, Zaskórski, 2015, s. 116). Cele warunkują także specyfikę procesów przetwarzania zasobów wejściowych na rezultaty wyjścia (rys. 3). Można przyjąć, że cele stanowią swoisty „pomost” pomiędzy uwarunkowaniami otoczenia przedsiębiorstwa i jego potencjałem wewnętrznym (tj. możliwościami i wymaganiami). Zmiany zachodzące w otoczeniu przedsiębiorstwa

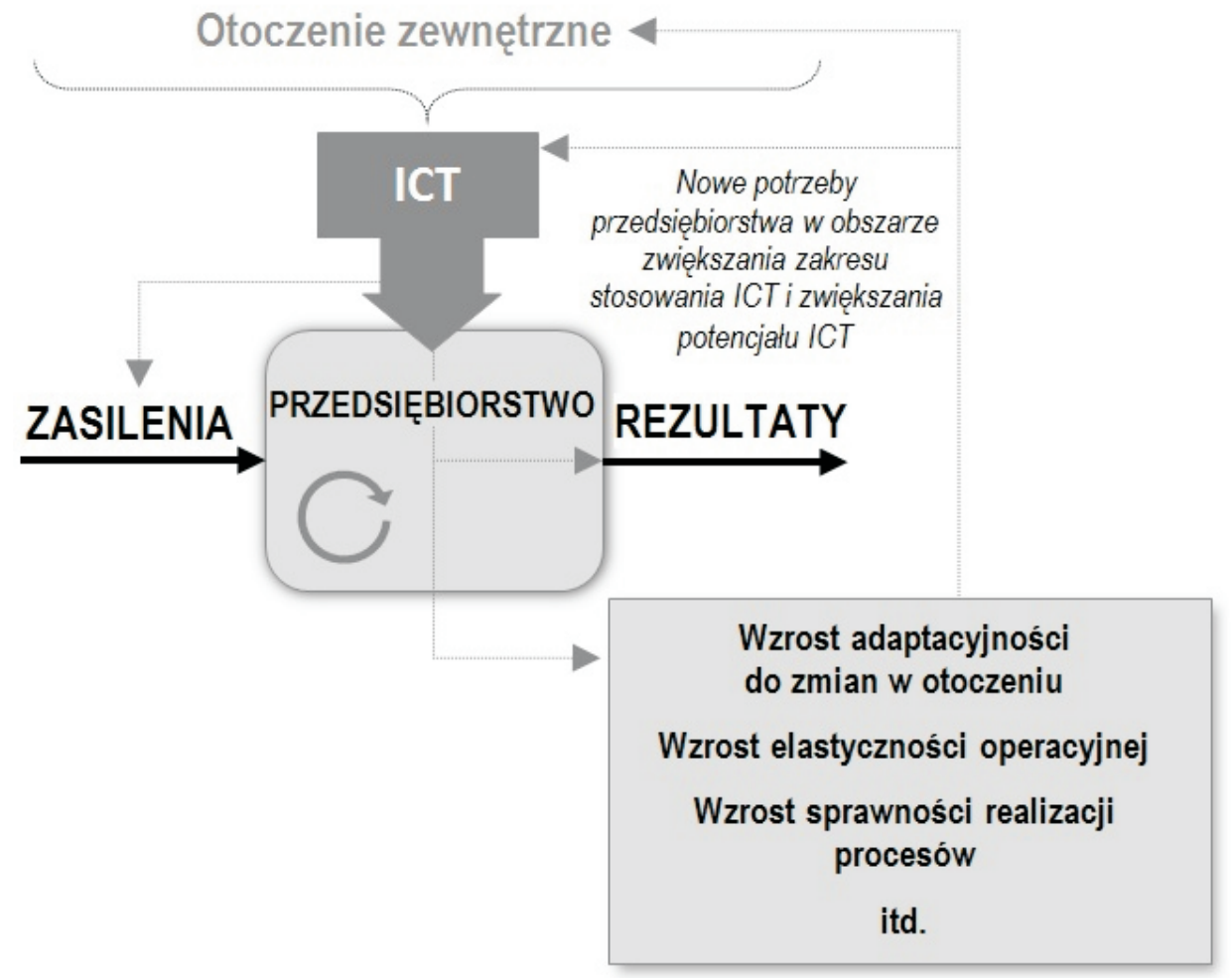

Rys. 3. Umiejscowienie technologii teleinformatycznych w doskonaleniu przedsiębiorstwa w kontekście procesów planowania

Źródło: opracowanie własne 
mogą skutkować modyfikacją struktury planów w dwóch aspektach: (1) aktualizacji celów odnośnie do wdrażania i doskonalenia stosowanych technologii teleinformatycznych oraz (2) kreowania nowych potrzeb informacyjnych na potrzeby usprawnienia procesów podstawowych i pomocniczych. Oba te aspekty są ze sobą sprzężone, ponieważ specyfika ICT i cele w obszarze ICT określają m.in. możliwości definiowania i spełniania potrzeb informacyjnych przedsiębiorstwa. Poprzez zmianę struktury planów (determinowaną potencjałem technologii teleinformatycznych) może być obserwowany m.in.: wzrost adaptacyjności przedsiębiorstwa do zmian w otoczeniu, wzrost jego elastyczności operacyjnej, a także zwiększenie sprawności i skuteczności realizacji procesów (Skrzypek, Hofman, 2010, s. 36-38), co przedstawiono na rysunku 3.

\section{Wyniki badania empirycznego}

\subsection{Metodyka badania i opis próby badawczej}

Podstawowym celem badania jest wskazanie, w jakim zakresie i w jakiej skali stosowane są technologie teleinformatyczne $\mathrm{w}$ realizacji procesów planowania w przedsiębiorstwach notowanych na rynku NewConnect w Polsce. Zastosowana metoda badawcza to Computer Assisted Self-Interviewing (CASI). Zakres przedmiotowy badania dotyczy zakresu i skali stosowania technologii teleinformatycznych w wybranych aspektach procesów planowania oraz wspierających je procesów zarządzania zasobami informacyjnymi. Zakres podmiotowy to przedsiębiorstwa notowane na rynku NewConnect, których siedziba znajduje się w Polsce i które prowadzą działalność głównie na terenie Polski oraz zatrudniają 10 lub więcej osób. Zakres czasowy badania to 2 miesiące (listopad-grudzień 2016 roku). Natomiast zakres przestrzenny obejmuje obszar całego kraju (16 województw w Polsce).

Wywiady zostały przeprowadzone $\mathrm{z}$ menedżerami lub kierownikami odpowiedzialnymi za obszar IT, relacje $\mathrm{z}$ otoczeniem lub innowacje - po 1 respondencie z każdego przedsiębiorstwa. W badaniu zastosowano dobór losowy systematyczny ( $\mathrm{z}$ uwzględnieniem kryterium wiodącego profilu działalności przedsiębiorstwa, wskazanego dla celów ewidencji na rynku NewConnect) w warstwach (warstwy odpowiadają wielkości przedsiębiorstwa). Liczebność próby badawczej to 60 przedsiębiorstw (co stanowi $28 \%$ podmiotów z populacji - w czasie przeprowadzania badania populację tworzyło 214 spółek).

Przeprowadzone badanie traktowane jest jako badanie pilotażowe, a otrzymane wyniki stanowią jedynie wskazanie kierunku dla dalszych badań oraz zwracają uwagę na podstawowe mechanizmy działania badanych przedsiębiorstw w zakresie wsparcia i realizacji procesów planistycznych z wykorzystaniem ICT. 
Wśród wszystkich 60 badanych przedsiębiorstw najwięcej podmiotów działa w branżach: handel, informatyka oraz przetwórstwo przemysłowe (po 11 przedsiębiorstw). Względnie dużo podmiotów działa również w branżach: budownictwo i usługi finansowe (po 8 przedsiębiorstw), a także doradztwo i szkolenia (7 przedsiębiorstw). Z kolei najmniej podmiotów działa w branżach: recykling (2 przedsiębiorstwa) oraz eco-energia i media (po 1 przedsiębiorstwie), co prezentuje tabela 1.

Tabela 1. Liczebność badanych przedsiębiorstw pod względem kryterium wiodącego profilu działalności $(\mathrm{N}=60)$

\begin{tabular}{|c|c|}
\hline Wiodący profil działalności (klasyfikacja NewConnect) & Liczba przedsiębiorstw \\
\hline Budownictwo & 8 \\
\hline Eco-energia & 1 \\
\hline Handel & 11 \\
\hline Informatyka & 1 \\
\hline Media & 2 \\
\hline Recykling & 8 \\
\hline Usługi finansowe & 11 \\
\hline Przetwórstwo przemysłowe & 7 \\
\hline Doradztwo i szkolenia & 60 \\
\hline Razem & \\
\hline
\end{tabular}

Źródło: opracowanie własne

W próbie dominują podmioty małe (tj. zatrudniające od 10 do 49 pracowników) - 37 przedsiębiorstw. Mniej liczną grupę stanowią podmioty średniej wielkości (tj. zatrudniające od 50 do 249 pracowników) - 22 przedsiębiorstwa. Najmniej liczna jest grupa podmiotów dużych (tj. zatrudniających 250 i więcej pracowników) - 1 przedsiębiorstwo (tab. 2).

W grupie przedsiębiorstw małych dominują podmioty działające w branżach: informatyka (8 przedsiębiorstw), handel (7 przedsiębiorstw) oraz usługi finansowe (6 przedsiębiorstw). Natomiast najmniej liczne są branże: eco-energia, media i recykling (po 1 podmiocie). W grupie przedsiębiorstw średniej wielkości dominują podmioty działające w branżach: przetwórstwo przemysłowe (7 przedsiębiorstw) oraz handel (4 przedsiębiorstwa). Natomiast jedyne przedsiębiorstwo zaklasyfikowane jako duże prowadzi działalność w branży recyklingu (tab. 2).

W próbie badawczej dominują podmioty „starsze” (10-15 lat działalności na rynku) i „młode” (4-9 lat działalności na rynku) - odpowiednio po 19 i 16 przedsiębiorstw. Najmniej liczna jest grupa przedsiębiorstw „starych” (powyżej 25 lat działalności na rynku) - 10 przedsiębiorstw (tab. 3). 
Tabela 2. Zestawienie kryteriów wiodącego profilu działalności oraz wielkości przedsiębiorstwa $(\mathrm{N}=60)$

\begin{tabular}{|c|c|c|c|c|}
\hline \multirow{2}{*}{$\begin{array}{c}\text { Wiodący profil } \\
\text { działalności } \\
\text { (klasyfikacja NewConnect) }\end{array}$} & \multicolumn{3}{|c|}{$\begin{array}{c}\text { Wielkość przedsiębiorstwa } \\
\text { (wg liczby zatrudnionych pracowników) } \\
\text { [liczba przedsiębiorstw] }\end{array}$} & \multirow{2}{*}{$\begin{array}{c}\text { Razem [liczba } \\
\text { przedsiębiorstw] }\end{array}$} \\
\hline & $\begin{array}{c}\text { Małe } \\
(10-49 \\
\text { pracowników) }\end{array}$ & $\begin{array}{c}\text { Średnie } \\
(50-249 \\
\text { pracowników) }\end{array}$ & $\begin{array}{c}\text { Duże } \\
\text { (250 i więcej } \\
\text { pracowników) }\end{array}$ & \\
\hline Budownictwo & 5 & 3 & 0 & 8 \\
\hline Eco-energia & 1 & 0 & 0 & 1 \\
\hline Handel & 7 & 4 & 0 & 11 \\
\hline Informatyka & 8 & 3 & 0 & 11 \\
\hline Media & 1 & 0 & 0 & 1 \\
\hline Recykling & 1 & 0 & 1 & 2 \\
\hline Usługi finansowe & 6 & 2 & 0 & 8 \\
\hline $\begin{array}{l}\text { Przetwórstwo } \\
\text { przemysłowe }\end{array}$ & 4 & 7 & 0 & 11 \\
\hline Doradztwo i szkolenia & 4 & 3 & 0 & 7 \\
\hline Razem & 37 & 22 & 1 & 60 \\
\hline
\end{tabular}

Źródło: opracowanie własne

Tabela 3.Zestawienie kryteriów wieku oraz wielkości przedsiębiorstwa $(\mathrm{N}=60)$

\begin{tabular}{|c|c|c|c|c|}
\hline \multirow{2}{*}{$\begin{array}{l}\text { Wiek } \\
\text { przedsiębiorstwa } \\
\text { [liczba lat }]\end{array}$} & \multicolumn{3}{|c|}{$\begin{array}{c}\text { Wielkość przedsiębiorstwa } \\
\text { (wg liczby zatrudnionych pracowników) } \\
{[\text { liczba przedsiębiorstw] }}\end{array}$} & \multirow{2}{*}{$\begin{array}{c}\text { Razem } \\
\text { [liczba } \\
\text { przedsiębiorstw] }\end{array}$} \\
\hline & $\begin{array}{c}\text { Małe } \\
(10-49 \\
\text { pracowników })\end{array}$ & $\begin{array}{c}\text { Średnie } \\
(50-249 \\
\text { pracowników })\end{array}$ & $\begin{array}{c}\text { Duże } \\
\text { (250 i więcej } \\
\text { pracowników) }\end{array}$ & \\
\hline 4-9 & 13 & 3 & 0 & 16 \\
\hline $10-15$ & 11 & 8 & 0 & 19 \\
\hline $16-24$ & 7 & 8 & 0 & 15 \\
\hline $25-30$ & 6 & 3 & 1 & 10 \\
\hline Razem & 37 & 22 & 1 & 60 \\
\hline
\end{tabular}

Źródło: opracowanie własne

Wśród badanych przedsiębiorstw małych dominują podmioty „młode” (13 przedsiębiorstw), a także „starsze” (11 przedsiębiorstw). W grupie przedsiębiorstw małych występuje najmniej podmiotów „starych” (6 przedsiębiorstw). W grupie przedsiębiorstw średniej wielkości przeważają podmioty „starsze” (pomiędzy 10. 
a 24. rokiem działalności na rynku) - 16 przedsiębiorstw. W tym zbiorze względnie mało jest podmiotów „młodych” i „starych” (po 3 przedsiębiorstwa). W zbiorze przedsiębiorstw dużych jest tylko jeden podmiot zaklasyfikowany do przedsiębiorstw „starych" (tab. 3).

Wśród badanych przedsiębiorstw najwięcej podmiotów deklaruje prowadzenie działalności w skali regionalnej (tj. na obszarze 1-8 województw w Polsce) i krajowej (tj. na obszarze 9-16 województw w Polsce) - wszyscy respondenci wskazali takie skale działania. Nieco mniej, bo 58 przedsiębiorstw, prowadzi działalność w skali lokalnej (tj. na obszarze 1 miasta, gminy bądź powiatu). Znacznie mniej przedsiębiorstw prowadzi działalność w skali europejskiej (tj. na obszarze przynajmniej 1 kraju w Europie poza Polską) - 25 podmiotów oraz międzynarodowej (tj. na obszarze przynajmniej 1 kraju na świecie poza Europą - w tym poza Polską) - 5 podmiotów (tab. 4.).

Tabela 4. Zestawienie kryteriów skali prowadzonej działalności oraz wielkości przedsiębiorstwa $(\mathrm{N}=60)$

\begin{tabular}{|c|c|c|c|c|c|}
\hline $\begin{array}{c}\text { Wielkość } \\
\text { przedsiębiorstwa } \\
\text { (wg liczby } \\
\text { zatrudnionych } \\
\text { pracowników) }\end{array}$ & \multicolumn{5}{|c|}{$\begin{array}{c}\text { Skala prowadzonej działalności } \\
\text { [liczba przedsiebiorstw] }\end{array}$} \\
\cline { 2 - 6 } & Lokalna & Regionalna & Krajowa & Europejska & Międzynarodowa \\
\hline $\begin{array}{c}\text { Małe } \\
(10-49 \text { pracowników) }\end{array}$ & 35 & 37 & 37 & 14 & 3 \\
\hline $\begin{array}{c}\text { Srednie } \\
(50-249 \text { pracowników) }\end{array}$ & 22 & 22 & 22 & 11 & 2 \\
\hline $\begin{array}{c}\text { Duże (250 i więcej } \\
\text { pracowników) }\end{array}$ & 1 & 1 & 1 & 0 & 0 \\
\hline Razem & 58 & 60 & 60 & 25 & 5 \\
\hline
\end{tabular}

Źródło: opracowanie własne

Przedsiębiorstwa, które prowadzą działalność w skali lokalnej, europejskiej i międzynarodowej, prowadzą również działalność w skali regionalnej i krajowej. Co więcej, w próbie badawczej można zaobserwować niski poziom internacjonalizacji działalności przedsiębiorstw. Ponadto, bez względu na skalę prowadzonej działalności, w każdej z pięciu grup (lokalnej, regionalnej, krajowej, europejskiej i międzynarodowej) dominują małe przedsiębiorstwa. Najmniejsze dysproporcje pomiędzy udziałem małych i średnich przedsiębiorstw występują w przypadku skali europejskiej i międzynarodowej (tab. 4). 


\subsection{Zastosowanie technologii teleinformatycznych $\mathrm{w}$ procesach planowania}

Spośród wszystkich badanych przedsiębiorstw 49 podmiotów wdraża technologie teleinformatyczne w obszarze magazynowania i przetwarzania kluczowych danych dla przedsiębiorstwa. Nieco mniej, bo po 46 podmiotów, wdraża ICT w obszarach pozyskiwania kluczowych danych oraz kreowania i udostępniania kluczowej dla przedsiębiorstwa wiedzy pracownikom i kooperantom. Nieco ponad połowa przedsiębiorstw ( 35 podmiotów) wdraża ICT stricte w obszarze procesów planowania, prognozowania i harmonogramowania (rys. 4).

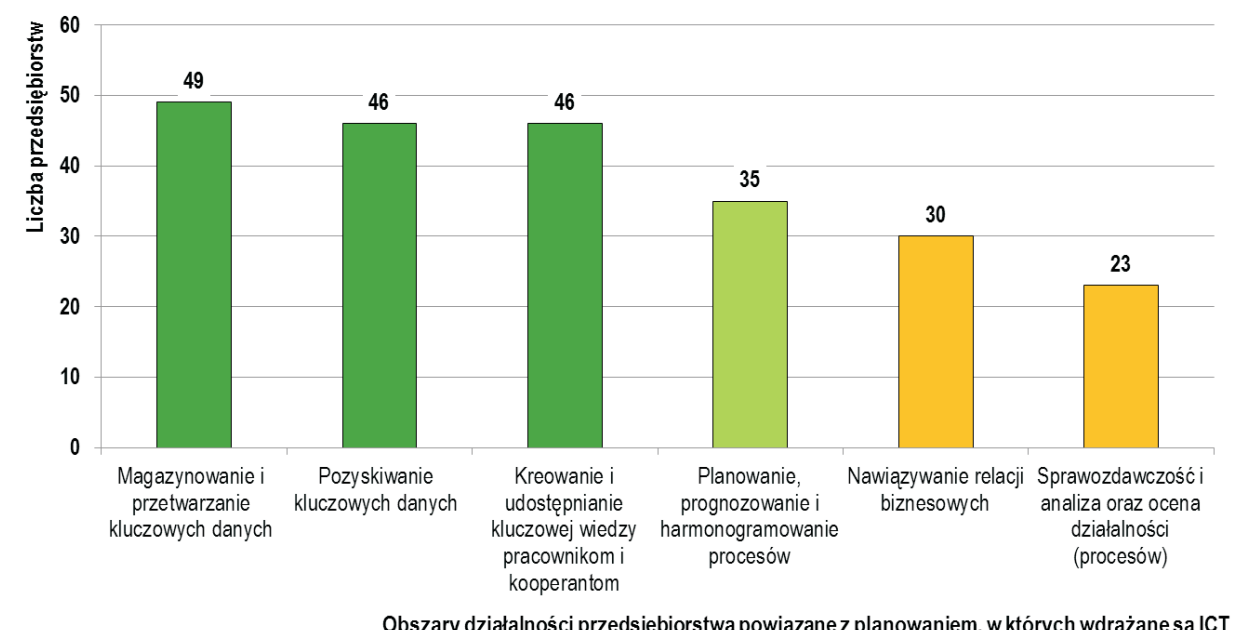

Rys. 4. Liczba przedsiębiorstw wdrażających ICT w wybranych obszarach swojej działalności powiązanych z procesami planowania $(\mathrm{N}=60)$

Źródło: opracowanie własne

Połowa badanych przedsiębiorstw wdraża technologie teleinformatyczne w obszarze związanym $\mathrm{z}$ nawiązywaniem relacji biznesowych $\mathrm{z}$ kooperantami należy jednak zaznaczyć, iż jest to obszar jedynie pośrednio związany z procesami planowania, który powinno się rozpatrywać w kontekście planowania operacyjnego i strategicznego rozwoju zasobów relacyjnych przedsiębiorstwa. Najmniej przedsiębiorstw wdraża ICT w obszarze sprawozdawczości i analizy oraz oceny działalności przedsiębiorstwa oraz procesów - 23 podmioty (rys. 4). 
Zdaniem respondentów wdrażanie ICT wpływa dodatnio (silnie lub słabo) ${ }^{4}$ na wszystkie komponenty procesów zarządzania zasobami informacyjnymi - jako swoiste elementy procesów planowania (rys. 5).

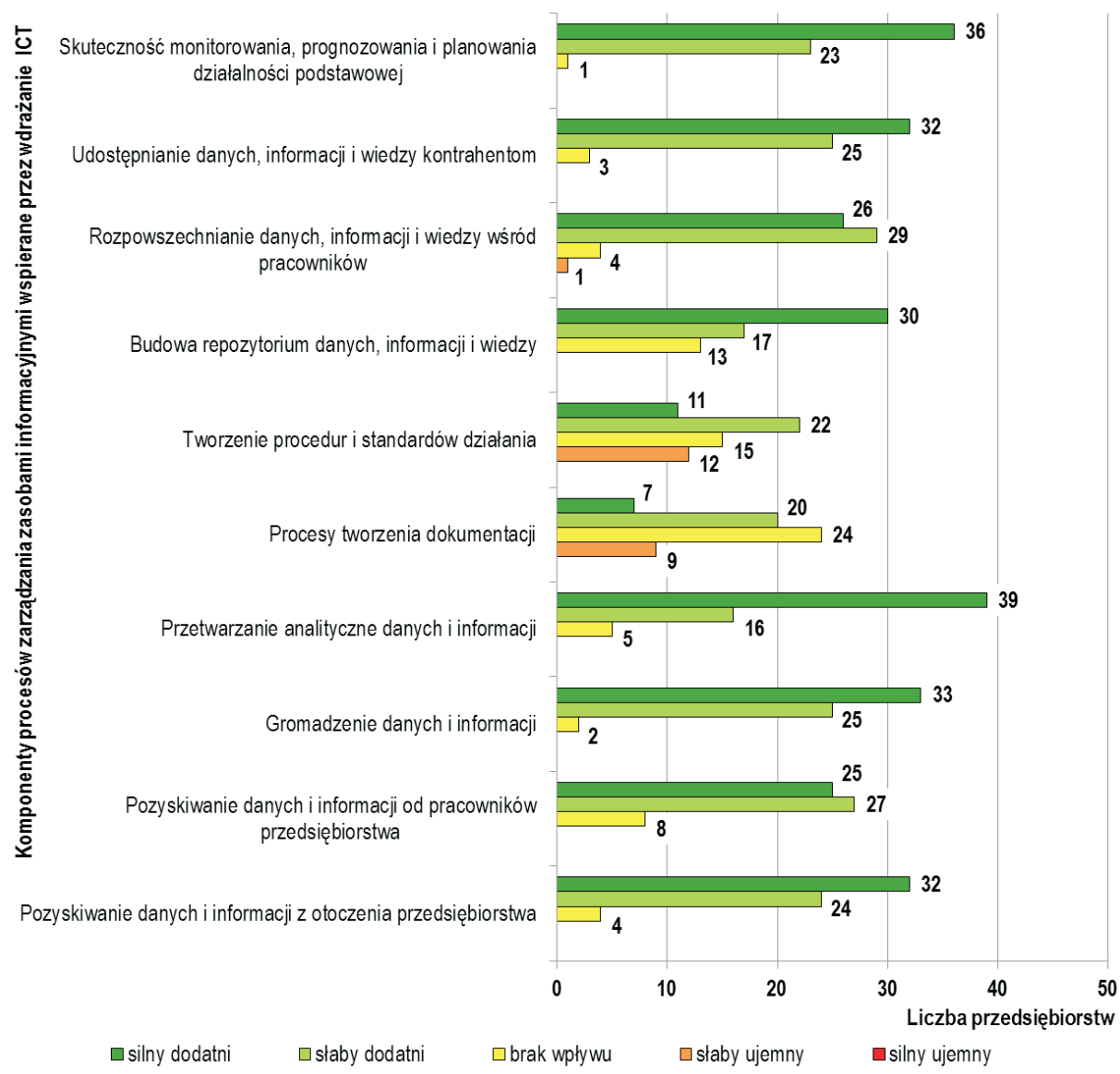

Rys. 5. Opinia respondentów na temat siły i kierunku wpływu wdrażania ICT na komponenty procesów zarządzania zasobami informacyjnymi $(\mathrm{N}=60)$

Źródło: opracowanie własne

$4 \quad$ Siła wplywu jest odzwierciedleniem poziomu usprawnienia lub osłabienia danego procesu poprzez wdrożenie ICT mierzonego średnią liczbą usprawnień wprowadzonych do procesów w skali roku (w przypadku wpływu dodatniego) lub średnią liczbą błędów i problemów pojawiających się w procesach (w skali roku) w wyniku wdrożenia ICT. Odpowiednio: wpływ silny - 15 i więcej usprawnień lub błędów oraz wpływ słaby - do maksymalnie 14 usprawnień lub błędów. Natomiast kierunek dodatni wpływu oznacza wzmocnienie/usprawnienie danego procesu poprzez wdrożenie ICT, zaś kierunek ujemny - osłabienie danego procesu. 
Według respondentów najsilniejszy dodatni wpływ wdrażania technologii teleinformatycznych ma miejsce w przypadku: przetwarzania analitycznego danych i informacji (39 przedsiębiorstw), zwiększania skuteczności monitorowania, prognozowania i planowania działalności podstawowej (36 przedsiębiorstw), gromadzenia danych i informacji (33 przedsiębiorstwa), a także pozyskiwania danych i informacji z otoczenia przedsiębiorstwa oraz udostępniania danych, informacji i wiedzy kontrahentom (po 32 przedsiębiorstwa) oraz budowy repozytorium danych, informacji i wiedzy (30 przedsiębiorstw).

Najwięcej respondentów wskazuje brak wpływu wdrażania ICT na następujące komponenty procesów zarządzania zasobami informacyjnymi: tworzenie dokumentacji (24 przedsiębiorstwa), tworzenie procedur i standardów działania (15 przedsiębiorstw), a także budowę repozytorium danych, informacji i wiedzy (13 przedsiębiorstw).

Z kolei słaby ujemny wpływ wdrażania ICT na komponenty procesów zarządzania zasobami informacyjnymi występuje $\mathrm{w}$ przypadku: tworzenia procedur i standardów działania (12 przedsiębiorstw), procesów tworzenia dokumentacji (9 przedsiębiorstw) oraz rozpowszechniania danych, informacji i wiedzy wśród pracowników (1 przedsiębiorstwo).

Warto również zaznaczyć, iż żaden respondent nie wskazał występowania silnego i jednocześnie ujemnego wpływu.

Zdaniem respondentów bardzo duży wpływ $w^{5}$ wdrażania technologii teleinformatycznych na wybrane aspekty procesów planowania występuje głównie w przypadkach: zwiększania zapotrzebowania na szkolenia - m.in. w kontekście planowania szkoleń związanych z procesami podstawowymi oraz szkoleń z zakresu planowania i zarządzania czasem (32 przedsiębiorstwa), zwiększania zakresu pozyskiwanych danych, informacji i wiedzy z otoczenia (18 przedsiębiorstw), a także zwiększania zakresu pozyskiwanych danych, informacji i wiedzy od pracowników (15 przedsiębiorstw) oraz zwiększania dopasowania danych, informacji i wiedzy do potrzeb informacyjnych na danym stanowisku bądź szczeblu kierowniczym - 11 przedsiębiorstw (rys. 6).

Duży wpływ wdrażania technologii teleinformatycznych na wybrane aspekty procesów planowania występuje, zdaniem respondentów, przede wszystkim w obszarach: zwiększania zakresu pozyskiwanych danych, informacji i wiedzy od pracowników (38 przedsiębiorstw), zwiększania zakresu pozyskiwanych danych, informacji i wiedzy z otoczenia (36 przedsiębiorstw), zwiększania zakresu i poziomu przetwarzania w kierunku funkcji aktywnych wspomagających planowanie i prognozowanie oraz analizę danych (28 przedsiębiorstw), zwiększania zapotrzebowania na szkolenia (23

\footnotetext{
Zakres wpływu oznacza odsetek procesów względem procesów aktualnie realizowanych w przedsiębiorstwie, jakie należy przekształcić/zmodernizować lub też wprowadzić jako nowe albo usunąć przy wdrażaniu ICT. Odpowiednio: zakres znikomy - do 5\%, zakres mały - do 10\%, zakres średni - do 30\%, zakres duży - do 50\% oraz zakres bardzo duży - 50\% i więcej.
} 
przedsiębiorstwa) oraz powstawania wyspecjalizowanych komórek organizacyjnych lub stanowisk związanych z pozyskiwaniem, przetwarzaniem i udostępnianiem danych, informacji i wiedzy (21 przedsiębiorstw).

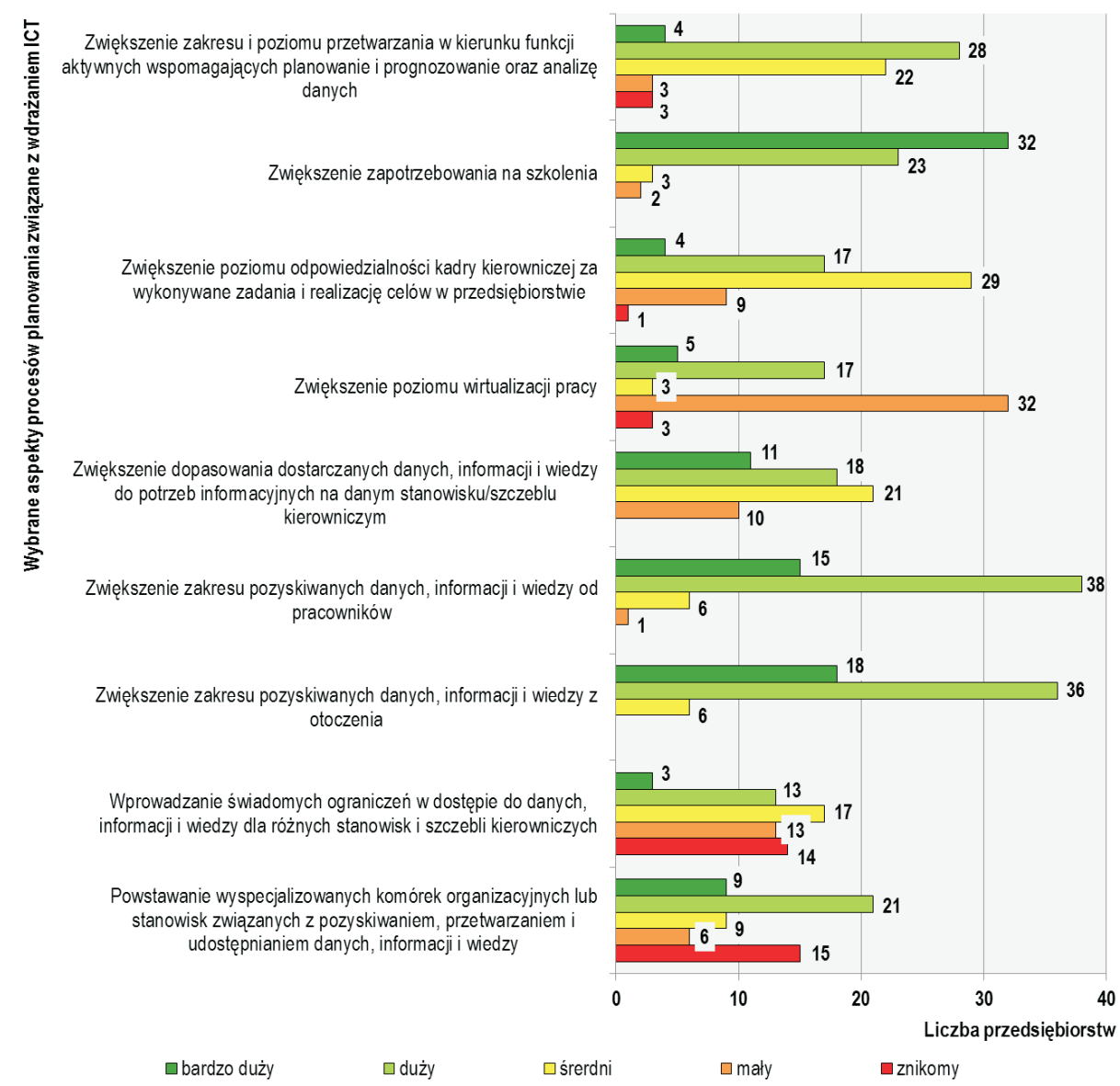

Rys. 6. Opinia respondentów na temat zakresu wpływu wdrażania ICT na wybrane aspekty procesów planowania $(\mathrm{N}=60)$

Źródło: opracowanie własne

Według respondentów mały wpływ wdrażania technologii teleinformatycznych na wybrane aspekty procesów planowania występuje przede wszystkim w obszarach: zwiększania poziomu wirtualizacji pracy (32 przedsiębiorstwa), wprowadzania świadomych ograniczeń w dostępie do danych, informacji i wiedzy dla różnych stanowisk i szczebli kierowniczych (13 przedsiębiorstw), jak również zwiększania poziomu odpowiedzialności kadry kierowniczej za wykonywane zadania i realizację celów (9 przedsiębiorstw). 
Znikomy wpływ wdrażania technologii teleinformatycznych na wybrane aspekty procesów planowania zdaniem respondentów występuje głównie w przypadku: powstawania wyspecjalizowanych komórek organizacyjnych lub stanowisk związanych z pozyskiwaniem, przetwarzaniem i udostępnianiem danych, informacji i wiedzy (15 przedsiębiorstw) oraz wprowadzania świadomych ograniczeń w dostępie do danych, informacji i wiedzy dla różnych stanowisk i szczebli kierowniczych (14 przedsiębiorstw).

\subsection{Dyskusja}

W badanych przedsiębiorstwach zakres wdrożenia technologii teleinformatycznych można uznać za zadowalający - sytuacja nie jest idealna, ale nie można powiedzieć, że ma miejsce swoiste „wykluczenie” technologiczne przedsiębiorstw w zakresie wdrażania i rozwijania ICT w procesach planowania. Sytuacja powinna jednak ulec poprawie, gdyż wymaga tego specyfika rynku NewConnect. Przyjmując, iż jest to rynek podmiotów innowacyjnych, badane przedsiębiorstwa powinny iść z duchem czasu i kreować swój potencjał rynkowy m.in. poprzez wdrażanie i rozwijanie innowacji procesowych i organizacyjnych (z wykorzystaniem różnych technologii teleinformatycznych). Planowanie traktowane jest współcześnie jako podstawowa funkcja menedżerska, która w zasadzie decyduje o szeroko rozumianej jakości innych funkcji, np. organizowania działań, kierowania operatywnego, monitorowania, nadzorowania, raportowania, czy też kontroli i oceny (Zaskórski, 2012, s. 43-47; Nowak, 2014, s. 16; Trocki, 2015, s. 21 i nast.). Co więcej, współczesne przedsiębiorstwa działają w warunkach tzw. szumu informacyjnego, w którym konieczne jest oddzielanie faktów i danych użytecznych od fałszu (Silver, 2014, s. 27 i nast.) Dlatego wsparcie procesów planowania przez ICT jest tak ważne.

Ogólnie można przyjąć, że respondenci dobrze postrzegają ICT i ich wpływ na wybrane aspekty procesów planowania i wspierające je procesy zarządzania zasobami informacyjnymi. Można nawet zauważyć, że wpływ technologii teleinformatycznych jest niekiedy delikatnie przeceniany. Respondenci to menedżerowie lub kierownicy odpowiedzialni za obszar IT, relacje z otoczeniem lub innowacje - w związku z czym można przyjąć, że udzielane przez nich odpowiedzi w zakresie wpływu ICT na procesy planowania mają potwierdzenie w rzeczywistości. Analizując uzyskane odpowiedzi, można zauważyć przede wszystkim, że:

1. Technologie teleinformatyczne są dość powszechnie wdrażane w obszarze pozyskiwania (z różnych źródeł), magazynowania i przetwarzania danych; respondenci oceniają również wpływ wdrożenia ICT w tych obszarach na procesy planowania jako silny lub bardzo silny;

2. Niedoceniany przez respondentów - w kontekście zakresu wpływu na procesy planowania - wydaje się obszar zwiększania wirtualizacji pracy; współcześnie procesy planowania, zwłaszcza w przedsiębiorstwach rozproszonych przestrzennie i informacyjnie, odbywają się w zespołach, których 
członkowie pracują w odległych od siebie lokalizacjach i dysponują odmiennymi kategoriami zasobów informacyjnych; w tym przypadku można było się spodziewać, iż respondenci wskażą, że wdrażanie ICT w większym zakresie wpływa na zwiększanie poziomu wirtualizacji pracy; uzyskana odpowiedź może sugerować jeszcze inną sytuację - w badanych przedsiębiorstwach wirtualizacja pracy jest już na wysokim poziomie i bieżące lub przyszłe wdrażanie ICT nie zwiększy znacząco jej skali i zakresu;

3. Wdrażanie ICT - w opinii respondentów - we względnie małym zakresie przekłada się na kształtowanie tzw. asymetrii informacji oraz rozbudowę struktury organizacyjnej w badanych przedsiębiorstwach o komórki i stanowiska odpowiedzialne za konstruktywne zarządzanie zasobami informacyjnymi i planowanie; taki stan rzeczy należy postrzegać jako swoiste zagrożenie dla przedsiębiorstw (lub też niewykorzystanie potencjału ICT w tym zakresie), które może mieć ujemne przełożenie m.in. na kształtowanie polityki bezpieczeństwa informacyjnego przedsiębiorstwa, czy też (w dalszej perspektywie) jego bezpieczeństwa ekonomicznego; taka ocena respondentów jest zastanawiająca, ponieważ jednocześnie wskazują oni w znacznej większości, że wdrażanie ICT wpływa silnie i dodatnio na budowę repozytorium danych, informacji i wiedzy w przedsiębiorstwie - takie repozytorium powinno być jednak odpowiednio osadzone w strukturze organizacyjnej i zarządzane przez przeznaczone do tego celu komórki;

4. Wdrażanie technologii teleinformatycznych $\mathrm{w}$ badanych przedsiębiorstwach w obszarze procesów planowania skutkuje zwiększonym zainteresowaniem menedżerów i kierowników szkoleniami (głównie w zakresie stosowania ICT i planowania); warto jednak zauważyć, że zwiększanie skali i zakresu szkoleń powinno być wprost proporcjonalne do zwiększania asymetrii informacji i tworzenia nowych stanowisk odpowiedzialnych za profesjonalne zarządzanie zasobami informacyjnymi - w przeciwnym razie efektywność tego typu szkoleń może być na niskim poziomie;

5. Zaskakujący, in minus, może być fakt, że respondenci z reguły oceniają na poziomie średnim lub małym zakres wpływu wdrażania ICT na zwiększanie dopasowania danych, informacji i wiedzy do potrzeb informacyjnych na danym stanowisku bądź szczeblu kierowniczym; taki stan rzeczy ma, niestety, odzwierciedlenie w braku skłonności respondentów do wdrażania na szeroką skalę założeń asymetrii informacji oraz tworzenia komórek organizacyjnych i stanowisk zajmujących się zarządzaniem zasobami informacyjnymi; stosowanie ICT na szeroką skalę w pozyskiwaniu danych, informacji i wiedzy zarówno $\mathrm{z}$ otoczenia, jak i od pracowników wymaga m.in. odpowiedniego dopasowania tych zasobów do stanowisk planistycznych i decyzyjnych (Orzechowski, 2008, s. 61 i nast.; Kaplan, Norton, 2011, s. 25 i nast.) - w przeciwnym razie w przedsiębiorstwach może być kreowana 
i rozpowszechniana (m.in. poprzez wadliwe merytorycznie procesy planowania) tzw. wiedza fałszywa (nieużyteczna), a w takiej sytuacji samo dostrzeganie potrzeby szkoleń z zakresu planowania niewiele pomoże;

6. W opinii respondentów wdrażanie ICT z reguły albo nie wywiera wpływu, albo wywiera słaby wpływ ujemny na procesy tworzenia dokumentacji oraz opracowywanie procedur i standardów działania; w kontekście realizacji procesów planowania nie jest to sytuacja korzystna - implementacja technologii teleinformatycznych powinna zwiększać przejrzystość procesów decyzyjnych, m.in. za sprawą ich algorytmizacji i modelowania, jak również powinna wspierać standaryzację dokumentacji i automatyzację jej generowania, np. w formie dedykowanych raportów i analiz;

7. W przypadku procesów planowania zaskakujący jest fakt, że respondenci dość często oceniają zakres wpływu wdrażania ICT na zwiększanie poziomu odpowiedzialności kadry kierowniczej za wykonywane zadania i realizację celów na poziomie średnim lub małym; stosowanie specjalistycznych i zaawansowanych technologii teleinformatycznych powinno skutkować wzrostem odpowiedzialności kadry kierowniczej za podejmowanie decyzje (w zakresie planowania) - człowiek powinien być postrzegany jako ,inteligentny" zasób przedsiębiorstwa ${ }^{6}$, podejmujący finalną decyzję i odpowiedzialny za jej prawidłowe wdrożenie;

8. Zdaniem respondentów wdrażanie ICT wpływa $\mathrm{z}$ reguły w dużym lub średnim stopniu na zwiększanie zakresu i poziomu przetwarzania w kierunku funkcji aktywnych wspomagających planowanie i prognozowanie oraz analizę danych; zakres wpływu powinien w tym przypadku kształtować się na wyższym poziomie, respondenci przyznają bowiem jednocześnie, że technologie teleinformatyczne wykorzystywane są powszechnie do pozyskiwania wiedzy z otoczenia, ale już niekoniecznie do samodzielnego kreowania wiedzy w środowisku wewnętrznym przedsiębiorstwa. Powstaje tutaj fundamentalne pytanie o koszty i racjonalność takiego działania skoro przedsiębiorstwo inwestuje we wdrożenie i rozwój ICT, to dlaczego nie wykorzystuje w pełni ich potencjału?

Konkludując, technologie teleinformatyczne powinny być wdrażane w przedsiębiorstwach w sposób „inteligentny”, tj. w miarę możliwości, potrzeb i wymagań przedsiębiorstw. Dopiero wtedy mogą być postrzegane jako źródło rzeczywistego wsparcia dla procesów planowania. Wdrażanie ICT nie powinno być „sztuką dla sztuki”, autonomiczną względem „tkanki” organizacyjnej - implementacja technologii teleinformatycznych powinna być spójna m.in. ze strukturą organizacyjną i powodować w niej określone zamiany (np. zwiększać poziom jej wirtualizacji, usieciowienia, elastyczności itp.) oraz zakresem kompetencji i odpowiedzialności pracowników różnych szczebli (zwłaszcza kierowniczych).

6 Człowiek, a nie technologie teleinformatyczne, pomimo przypisywanego im atrybutu ,inteligencji”. 


\subsection{Ograniczenia badawcze}

1. Dokonując analizy otrzymanych wyników, należy uwzględnić fakt, że badanie przeprowadzono na względnie małej próbie - zatem można je uznać wyłącznie za pilotaż oraz podstawę merytoryczną i metodyczną dla badań właściwych (w formie badania pełnego). Trudno jest zatem zastosować wnioskowanie na całej populacji - wyciągnięte wnioski można traktować jedynie jako spostrzeżenia odnoszące się do badanych przedsiębiorstw, jak również podstawę do stworzenia tzw. dobrych praktyk w zakresie wdrażania ICT w przedsiębiorstwach notowanych na rynku NewConnect w Polsce. Warto jednak pamiętać, że rynek ten jest dość zróżnicowany, np. pod względem liczby branż, wieku przedsiębiorstw czy też skali ich działania. Trudno jest więc opracować zestaw dobrych praktyk dla ogółu przedsiębiorstw.

2. Co więcej, badano wyłącznie opinie respondentów, co mogło mieć wpływ na zniekształcenie rzeczywistego obrazu sytuacji (respondenci mogli wykazywać skłonność do udzielania odpowiedzi, które uważali za korzystne dla dobrego wizerunku ich przedsiębiorstwa, zwłaszcza że odpowiadali w obecności ankietera). W badaniu skoncentrowano się także wyłącznie na wybranych aspektach procesów planowania i zarządzania zasobami informacyjnymi, głównie ze względu na koszty badania. Zatem analiza wyników może wydawać się miejscami wybiórcza i nazbyt zawężona merytorycznie.

\section{Podsumowanie}

Wdrażanie technologii teleinformatycznych w procesach planowania, jak również we wspierających je procesach zarządzania zasobami informacyjnymi, jest współcześnie ważnym obszarem działania przedsiębiorstw ukierunkowanych na wzrost innowacyjności i działalność w warunkach silnej konkurencji i ryzyka (np. rynkowego i finansowego). Dlatego implementacja ICT w przedsiębiorstwach notowanych na rynku NewConnect wydaje się działaniem zasadnym. W branżach innowacyjnych poszukiwanie źródeł potencjału konkurencyjnego sprowadza się w większości przypadków do zdolności do kreowania wiedzy i umiejętnego zarządzania tą wiedzą. Wsparcie funkcji planowania przez technologie teleinformatyczne daje podstawy do takiego właśnie działania. Kreowana wiedza, poprzez jej spożytkowanie w opracowywaniu planów dla różnych szczebli kierowniczych, może skutkować eliminacją lub osłabieniem określonych czynników ryzyka, jak również stymulować przedsiębiorstwa do wzrostu efektywności w zakresie działalności podstawowej (skoncentrowanej m.in. wokół kreowania, wdrażania i komercjalizacji innowacji).

$\mathrm{Z}$ przeprowadzonego badania wynika, że technologie teleinformatyczne są dostrzegane przez przedsiębiorstwa notowane na rynku NewConnect i powszechnie 
wdrażane w kluczowych aspektach procesów planowania i zarządzania zasobami informacyjnymi (realizowanych na potrzeby planowania). Można więc zaobserwować skłonność przedsiębiorstw do holistycznego (ale na niskim - jeszcze - poziomie) podejścia do realizacji procesów planowania z wykorzystaniem ICT. Jednakże dodatni wpływ technologii teleinformatycznych na tego typu procesy nie zawsze jest doceniany, zwłaszcza w zakresie wsparcia działań analitycznych. Kadra kierownicza w badanych przedsiębiorstwach powinna być świadoma tego, że ICT współcześnie nie służą tylko do pozyskiwania i magazynowania danych oraz informacji, ale również (o ile nie przede wszystkim - w tak konkurencyjnych branżach, jak ma to miejsce na rynku NewConnect) do kreowania i dyfuzji wiedzy. Wdrażanie ICT powinno również skutkować dopasowaniem po stronie przedsiębiorstw, np. w zakresie zmian strukturalnych (m.in. w zakresie poziomu wirtualizacji działania, wdrażania założeń asymetrii informacji oraz tworzenia stanowisk i komórek wyspecjalizowanych w zarządzaniu zasobami informacyjnymi). Może mieć to bowiem znaczenie w zwiększaniu efektywności, wydajności i skuteczności procesów planowania.

\section{BIBLIOGRAFIA}

[1] BомвіАк E., 2017, Human resources risk as an aspect of human resources management in turbulent environment, [w:] F. Pînzaru, A. Zbuchea, C. Brătianu, E. Vătămănescu, A. Mitan (red.), Shift! Major challenges of today's economy, Tritonic Publishing House, Bucharest.

[2] Cielemęcкi M., Вомвіак E., 2016, Ewolucja otoczenia organizacji - zarys problematyki, „Zeszyty Naukowe Uniwersytetu Przyrodniczo-Humanistycznego w Siedlcach. Administracja i Zarządzanie", Nr 38.

[3] Drab-Kurowska A., 2011, Nowoczesne technologie w małych i średnich przedsiębiorstwach, [w:] A. Drab-Kurowska, A. Sokół, Małe i średnie przedsiębiorstwa wobec wyzwań rozwoju technologii XXI wieku, CeDeWu, Warszawa.

[4] Goodwin P., Wright G., 2011, Analiza decyzji, Wolters Kluwer, Warszawa.

[5] Griffin R.W., 2006, Podstawy zarządzania organizacjami, Wydawnictwo Naukowe PWN, Warszawa.

[6] Jurga A., 2010, Technologia teleinformatyczna w organizacji wirtualnej, Wydawnictwo Politechniki Poznańskiej, Poznań.

[7] Kaplan R.S., NoRTon D.P., 2011, Dopasowanie w biznesie. Jak stosować strategiczną kartę wyników. Alignment, Gdańskie Wydawnictwo Psychologiczne, Gdańsk.

[8] Kasiewicz S., Rogowski W., 2006, Ryzyko a wzrost wartości przedsiębiorstwa, „Kwartalnik Nauk o Przedsiębiorstwie", Nr 1.

[9] Koźmiński A.K., Latusek-Jurczak D., 2011, Rozwój teorii organizacji. Od systemu do sieci, Wolters Kluwer, Warszawa.

[10] Larose D.T., 2006, Odkrywanie wiedzy z danych. Wprowadzenie do eksploracji danych, Wydawnictwo Naukowe PWN, Warszawa.

[11] Mintzberg H., 2013, Zarządzanie, Wolters Kluwer, Warszawa. 
[12] Niemczyк J., 2013, Strategia. Od planu do sieci, Wydawnictwo Uniwersytetu Ekonomicznego we Wrocławiu, Wrocław.

[13] NowaK M., 2014, Uwarunkowania procesów decyzyjnych w projektach, [w:] M. Nowak (red.), Wspomaganie decyzji w planowaniu projektów, Difin, Warszawa.

[14] Orzechowski R., 2008, Budowanie wartości przedsiębiorstwa z wykorzystaniem IT, Oficyna Wydawnicza Szkoła Główna Handlowa w Warszawie, Warszawa.

[15] Silver N., 2014, Sygnał i szum. Sztuka prognozowania w erze technologii, Wydawnictwo Helion, Gliwice.

[16] Skrzy pek E., Hofman M., 2010, Zarządzanie procesami w przedsiębiorstwie. Identyfikowanie, pomiar, usprawnianie, Wolters Kluwer, Warszawa.

[17] Sosı́́ski D., 2011, Rola IT w zarządzaniu zintegrowanym ryzykiem, [w:] S. Kasiewicz (red.), Zarzadzanie zintegrowanym ryzykiem przedsiębiorstwa w Polsce. Kierunki i narzędzia, Wolters Kluwer, Warszawa.

[18] Surma J., 2009, Business Intelligence. Systemy wspomagania decyzji biznesowych, Wydawnictwo Naukowe PWN, Warszawa.

[19] Trocki M., 2015, Podstawy planowania przebiegu projektów, [w:] M. Trocki, P. Wyrozębski (red.), Planowanie przebiegu projektów, Oficyna Wydawnicza Szkoła Główna Handlowa w Warszawie, Warszawa.

[20] TureK J., 2012, Zintegrowane zarzadzanie ryzykiem w przedsiębiorstwie funkcjonujacym $w$ turbulentnym otoczeniu, [w:] T. Pakulska (red.), Przedsiębiorstwo a otoczenie. Oddziaływanie, skutki, Oficyna Wydawnicza Szkoła Główna Handlowa w Warszawie, Warszawa.

[21] Wojtysiak-KotlaRski M., 2011, Teoria przedsiębiorstwa a koncepcje zarządzania i praktyka biznesu, Oficyna Wydawnicza Szkoła Główna Handlowa w Warszawie, Warszawa.

[22] WoźNiak J., Wereda W., (w druku), Information and Communication Technologies (ICTs) in Enterprises on the Over The Counter (OTC) Markets in European Union. Case Study of Polish NewConnect Market, [w:] A.M. Dima (red.), Doing Business in Europe - Economic Integration Processes, Policies, and the Business Environment, Springer International Publishing, Cham.

[23] WoźNIAK J., ZAsKóRsKi P., 2015, Systemowe aspekty projektowania i doskonalenia organizacji oraz kształtowania jej bezpieczeństwa, [w:] J. Woźniak (red.), Projektowanie i doskonalenie organizacji $w$ aspekcie jej bezpieczeństwa i usprawniania procesów informacyjno-decyzyjnych, Wojskowa Akademia Techniczna, Warszawa.

[24] WRóBel P., 2010, Informacja w systemach zarządzania, [w:] S. Wrycza (red.), Informatyka ekonomiczna, Polskie Wydawnictwo Ekonomiczne, Warszawa.

[25] Wrycza S., 2010, Przedmowa, [w:] S. Wrycza (red.), Informatyka ekonomiczna, Polskie Wydawnictwo Ekonomiczne, Warszawa.

[26] Zaskórski P., 2012, Asymetria informacyjna w zarządzaniu procesami, Wojskowa Akademia Techniczna, Warszawa.

[27] Zaskórski P., 2014, Współczesna organizacja jako system w systemie i nad systemem, [w:] K. Piotrkowski, Z. Wojciechowski (red.), Uniwersalność versus różnorodność w teorii i praktyce zarządzania, Wojskowa Akademia Techniczna, Warszawa.

\section{NETOGRAFIA}

[1] ISO, 2009, ISO 31000:2009(en): Risk management - Principles and guidelines, https://www.iso. org/obp/ui/\#iso:std:iso:31000:ed-1:v1:en (18.07.2017). 
[2] ISTSHARE.EU, 2017, ICT - Technologie informacyjno-komunikacyjne, https://www.istshare.eu/ ict-technologie-informacyjno-komunikacyjne.html (20.07.2017).

[3] NewConnect, 2015, Raport o rynku NewConnect. 2015 rok. Podsumowanie funkcjonowania pierwszej alternatywnej platformy obrotu $w$ Polsce, https://www.gpw.pl/pub/files/PDF/2015-0525_NEWCONNECTraport2015.PDF (15.06.2017).

[4] NewConnect, 2017, https://newconnect.pl/o-rynku (21.12.2017).

[5] KRYSIAK Z., 2011, Silna kultura zarządzania ryzykiem jako cecha nowoczesnych organizacji, „E-mentor”, Nr 2 (39), http://www.e-mentor.edu.pl/artykul/index/numer/39/id/822 (25.10.2016). 